\title{
PEMBENTUKAN DAN PEMBINAAN KELAS REMAJA SEHAT DI PONDOK PESANTREN
}

\author{
ESTABLISHMENT AND COACHING OF HEALTHY TEENAGE CLASS \\ IN PONDOK PESANTREN
}

\author{
${ }^{1)}$ Mustika Dewi, ${ }^{2)}$ Mega Ulfah, ${ }^{3)}$ Fatmawati, ${ }^{4)}$ Ningrum Paramita Sari, ${ }^{5)}$ Nur Aini Retno \\ Hastuti, ${ }^{6}$ Rahmadian Hanifa R, ${ }^{7}$ Purwarani Febria Damayanti, ${ }^{8}$ R.A Rahmawati Nurul F \\ ${ }^{1,2,3,4,5,6,7,8)}$ Fakultas Kedokteran Universitas Brawijaya Program Studi S1 Kebidanan \\ Jl. Veteran Malang \\ mustikadewi@ub.ac.id,megaulfah@ymail.com,fatmawatibetty26@gmail.com, \\ ningrum.paramita@gmail.com,rahmadian.anwar@ub.ac.id, nurainiretno@ub.ac.id, \\ ra.rahmawati98@yahoo.com, rani123124@gmail.com
}

\begin{abstract}
ABSTRAK
Sekolah merupakan wahana pendidikan yang tepat untuk melakukan promosi kesehatan reproduksi remaja, dalam rangka mendukung program pemerintah yang bertajuk pelayanan kesehatan peduli remaja (PKPR). Pondok Pesantren Daarul Ukhuwwah Putri Malang merupakan salah satu sekolah yang berbasis pesantren yang mendidik remaja putri usia 12-18 tahun. Remaja merupakan masa pencarian identitas diri, yang memiliki rasa ingin tahu yang sangat tinggi.Informasi yang berimbang sangat dibutuhkan remaja dalam menjalani masa pertumbuhan dan perkembangan, khususnya terkait kesehatan reproduksi.Teknologi informasi memberikan kontribusi pada tahap perkembangan ini, sehingga memiliki dampak positif maupun negatif.Tujuan kegiatan ini adalah (1) Meningkatkan pengatahuan tentang kesehatan reproduksi remaja, (2) Pembentukankelas remaja sehat, dan (3) Membuat program kerja kelas remaja.Sasaran pembentukan kelas remaja adalah remaja putri (santri) yang berjumlah 10 orang yang disebut denganvolunteeratau kader kesehatan remaja.Metode kegiatan berupa branstroming, focus group discussion dan ceramah. Kegiatan ini dilakukan sebanyak5 (lima) kali kegiatan yang membahas dan mendiskusikan tentang kesehatan reproduksi.Voluneteer diharapkan dapat memandu teman-temannya dalam memperoleh informasi yang benar tentang kesehatan reproduksi.Terdapat peningkatan pengetahuan remaja tentang kesehatan reproduksi sebanyak $25.6 \%$ setelah dilakukan pembinanaan kelas remaja.Untuk keberlanjutan kelas remaja, maka dibuat program kerja kelas remaja sehat di pondok pesantren, dengan kegiatan berkala mingguan, bulanan dan tahunan. Kegiatan ini akan dilaksanakan oleh volunteer di bawah binaan guru atau ustadzah Pembina kelas remaja sehat di pondok pesantren.
\end{abstract}

Kata kunci : Kelas Remaja. Remaja. Kesehatan Reproduksi

\section{ABSTRACT}

School is a primary place for doing health promotion especially about teenage reproduction in order to support government program which is Pelayanan Kesehatan Peduli Remaja (PKPR). Daarul Ukhuwwah Dormitory School is one of dormitory school for teenager age 12-18 years old. Teenager usually tried to find their identity in this age. They are in high curiosity. Balance information is needed for teenager for their growth and development especially about health reproduction. Information and technology gave negative and positive impact for teenager. Making a discussion group in health might give positive impact for teenager. The purpose of this activity were (1) increase adolescence knowledge about reproduction health (2) making adolescence group (3) making work programs for adolescence group. The target was 


\section{Mustika Dewi,Mega Ulfah, Fatmawati, Ningrum Paramita Sari, Nur Aini Retno Hastuti,Rahmadian Hanifa R, Purwarani Febria Damayanti, R.A Rahmawati Nurul F Pembentukan Dan Pembinaan Kelas Remaja Sehat Di Pondok Pesantren}

female adolescence called "volunteer" about 10 persons. The method were brainstorming, focus groupdiscussionand lecture. The volunteer had been educated 5 times by discussing about health reproduction. We hope that Volunteer would guide their friend in looking for right information about health reproduction. There was increasing of teenage's knowledge in healthreproduction about 25,6\%. For continuity, it has been made a program named health adolescence group at school with continue activity in health. This activity has been done by volunteer in under control by teacher.

Key words: Adolescence Group, Adolescence, Reproduction Health

Submitted:21 Nopember 2017 Revision: 21 Mei $2018 \quad$ Accepted:26 Mei 2018

\section{PENDAHULUAN}

Pondok Pesantren Daarul Ukhuwwah Putri adalah wahana pemberdayaan masyarakat yang bergerak di bidang pendidikan di Malang. Pondok Putri Darul Ukhuwwah terdiri dari remaja putri usia sekitar 12-15 tahun.Usia remaja merupakan periode penting untuk menjalin hubungan dengan orangtua. Di pondok pesantren dimana remaja tinggal atau mondok, maka guru atau ustadzah adalah orang kedua bagi remaja(Birkeland, Breivik, \& Wold, 2014).Hubungan antara sesama santri di pondok juga sangat mempengaruhi perilaku kebiasaan merawat kesehatan dirinya, karena mereka memiliki hidup bersama(Ellis, ChungHall, \& Dumas, 2013; Ellis \& Wolfe, 2009).

Perkembangan teknologi informasi mempengaruhi sikap, hubungan sosial, danmemandu kognisi, ingatan, serta perhatian remaja, sehingga dirasa perlu pengimbang informasi yang diterima oleh remaja, terutama terkait kesehatan reproduksi(Gorrese \& Ruggieri, 2012).Agar remaja memiliki tanggung jawab dalam menjaga kesehatan dirinya, sebagai asset berharga bagi generasi penerus bangsa.

Menurut SDKI tahun 2012 bahwa remaja perempuan yang mengetahui pelayanan dan informasi tentang kesehatan reproduksi hanya 7.2\%(Kemenkes RI, 2014).Remaja perempuan yang sudah menstruasi perlu mengatahui tentang kesehatan reproduksi dan perilaku yang hygienis dalam merawat dirinya.
Kurangnya informasi tentang kesehatan reproduksi akan berdampak terhadap perilaku yang kurang hygienis. Mikroorganisme pathogen seperti jamur, bakteri, virus akan mudahmenggangu kesehatan terutama pada organ reproduksi. Pada survey awal ditemukan $17 \%$ remaja akan mengeluhkan keputihan.

Keputihan (leukorea) dapat disebabkan oleh mikroorganisme yang hidup di daerah yang lembab, persisnya dalam cairan vagina.Jika keputihan ini tidak segera membaik, hal ini dapatdisertaiinfeksi.Biasanya keadaan ini ditandaidengan banyaknya cairan keputihan, gatal yang disertai bau tidak sedap yang keluar dari vagina.Namun ada kalanya tidak memberikan gejala dan tidak dikeluhkan sama sekali. Oleh karena ituremaja perempuan harus benar-benar dapat menjaga kesehatan dan kebersihan organ reproduksi, agar tidak menimbulkan perkembangbiakan mikro organisme yang mengganggu fungsi organ reproduksi dikemudian hari. Pengetahuan tentang personal hygiene sangat penting untuk menjaga kesehatan reproduksi remaja (Andrew, 2010).

Pembentukan dan pembinaan kelas remaja, merupakan sarana untuk memberikan pengetahuan bagi remaja tentang kesehatan reproduksi.Program kelas remaja harus dilakukan secara berkelanjutan di sekolah. Sekolah dapat memberdayakan siswa atau santri sebagai kader kesehatan atau penyambung informasi dalam kelompok 


\section{Mustika Dewi,Mega Ulfah, Fatmawati, Ningrum Paramita Sari, Nur Aini Retno Hastuti,Rahmadian Hanifa R, Purwarani Febria Damayanti, R.A Rahmawati Nurul F Pembentukan Dan Pembinaan Kelas Remaja Sehat Di Pondok Pesantren}

teman sebayanya (Andrew, 2010 ; Marion, Laursen, Zettergren, \& Bergman, 2013).

Lingkungan eksternal maupun internal sekolah atau pondok pesantren harus memberikan perhatian yang serius dalam menghadapi perkembangan remaja.Demikian juga halnya dengan pengaruh NAPZA, dan rokok serta penyakit menular seksual merupakan materi yang harus mereka ketahui karenaerat kaitannya dengan kesehatan reproduksi dan masa depan mereka(Andrew, 2010; Irianto, 2015).

Kegiatan pengabdian masyarakat ini bertujuan untuk : (1) meningkatkan pengetahuan remaja tentang kesehatan reproduksi, (2) membentuk kelas remaja sehat, dan (3) membuat rencana program kerja kelas remaja sehat. Kelas remaja sehat yang dibentuk diharapkan dapat berjalan secara berkesinambungan dibawah bimbingan ustadzah pembina di pondok pesantren.

\section{METODE KEGIATAN}

Kegiatan ini dilaksanakan dalam 5 (lima) kali kegiatan diskusi terpimpin di Pondok Pesantren Darul UkhuwwahPutri di Malang. Metode kegiatan berupa brainstorming, small group discussion (SGD) dan ceramah dengan menggunakan media seperti LCD, leaflet, laptop, microfon, media/alat bantu penyuluhan terkait organ reproduksi dan alat tulis.

Monitoring dan evaluasi program dilakukan oleh fasilitator / penulis selaku penggagas "Kelas Remaja Sehat" setiap dua kali satu bulan.

Sistem monitoring didapatkan melalui diskusi dan brainstormingdari seperangkat indikator untuk menilai, yaitu :

1. Apakah seluruh kegiatan yang di agendakan diikuti oleh semua volunteer secara maksimal, dan bagaimana kemajuannya, adakah kendala atau masalah dari segi waktu dan topik diskusi yang dipilih.

2. Topik diskusi yang dipilih antara lain : pengenalan anatomi organ reproduksi, menarche, menstruasi, dampak dari kemajuan teknologi terhadap pergaulan remana, NAPZA dan rokok, kebersihan diri remaja serta gizi dalam reproduksi.

3. Apakah input dan proses yang dilakukan menghasilkan perbaikan ke arah peningkatan pengetahuan.

4. Apakah umpan balik tentang output dan proses dikaitkan dengan input

5. Adakah faktor lingkungan atau eksternal (masyarakat, geografis, kebijakan setempat) dan faktor internal (volunteer) mempengaruhi pelaksanaan "Program Kelas Remaja Sehat"

Uraian Pelaksanaan Kegiatan :

1. Persiapan, yaitu pemilihan relawan kesehatan reproduksi atau volunteer sebanyak 10 orang santri, pemberian booklet kesehatan reproduksi untuk volunteer dan pembentukan "Program Kelas Remaja Sehat".

2. Pelaksanaan, yaitu pembinaan kelas remaja yang dilakukan dengan metode diskusi dan branstroming selama 2 (dua) kali dalam sebulan dengan materi organ reproduksi wanita dan pria, menarche dan menstruasi, gizi remaja, personal hygiene dan penyakit kulit yang sering terjadi akibat personal hygiene yang kurang, penugasan melakukan promosi kesehatan melalui poster, pembentukan struktur organisasi "Kelas Remaja Sehat", penyusunan program kerja kelas remaja sehat, pelaksanaan salah satu program kelas remaja sehat yaitu mengadakan seminar kesehatan reproduksi dengan sasaran selurh santri di pondok pesantren dan evaluasi. 


\section{Mustika Dewi,Mega Ulfah, Fatmawati, Ningrum Paramita Sari, Nur Aini Retno Hastuti,Rahmadian Hanifa R, Purwarani Febria Damayanti, R.A Rahmawati Nurul F}

Pembentukan Dan Pembinaan Kelas Remaja Sehat Di Pondok Pesantren

\section{HASIL DAN PEMBAHASAN}

Hasil Kegiatan ini adalah sebagai berikut :

1. Pelaksanaan kegiatan yang dilakukan 2 kali sebulan berupa pembinaan kelas remaja sehat dengan waktu pelaksanaan kegiatan pada sore hari, dengan alokasi waktu 90 menit, setelah aktifitas pondok pada pagi hari

yang cukup padat. Telah dilakukan pre dan post test pada kegiatan pembinaan dengan hasil peningkatan pengetahuan sebagai berikut :

Tabel 1. Peningkatan pengetahuan remaja dari hasil pre dan post test

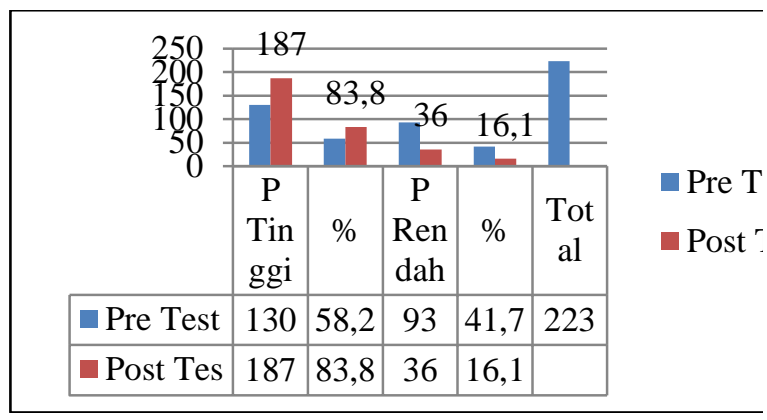

Berdasarkan tabel di atas dapat dilihat adanya peningkatan pengetahuan remaja tentang materi kesehatan reproduksi yang diberikan sebanyak $25.6 \%$.

2. Pembentukan struktur organisasi "Kelas Remaja Sehat" di Pondok Pesantren Daarul Ukhuwwah Putri, dengan kader kesehatan atau volunteer bejumlah 10 orang, yang terdiri dari perwakilan santri (remaja putri) di Pondok Pesantren.

Tabel 2. Struktur organisasi kelas remaja sehat periode 2017-2018

\begin{tabular}{crc}
\hline NO & NAMA & JABATAN \\
\hline $\mathbf{1}$ & Sobrina Naura & Ketua \\
\hline
\end{tabular}

$\begin{array}{clc}\mathbf{2} & \text { Izza Naila Zohro } & \text { Wakil Ketua } \\ \mathbf{3} & \text { Afifah Nurul Adilah } & \text { Bendahara } \\ & \text { Afifah Afra Nur } & \text { Sekretaris } \\ & \text { Fatihah } & \text { Anggota } \\ \mathbf{5} & \text { Nur Islamiyah Al } & \text { Astiqomah } \\ & \text { Anggota } \\ \mathbf{6} & \begin{array}{l}\text { Rika Aulia Dewi } \\ \mathbf{7}\end{array} & \text { Afifah Mau'izhatul } \\ & \text { Hasanah } & \text { Anggota } \\ \mathbf{8} & \text { Tsalastah } & \text { Anggota } \\ & \text { Mutammimah } & \\ \mathbf{9} & \begin{array}{l}\text { Qotrunnada Salsabila } \\ \mathbf{1 0}\end{array} & \text { Qotrunnada Salsabila } \\ & \text { R.A } & \text { Anggota } \\ & & \text { Anggota } \\ \end{array}$

3. Penyusunan program kerja kelas remaja sehat, terlampir.

Program kerja kelas remaja sehat di Pondok Pesantren Daarul Ukhuwwah yang telah disusu adalah sebagai berikut :

a. Program Kerja Tahunan : Mengadakan seminar tentang kesehatan.

b. Program Kerja Bulanan : Mengadakan kerja bakti untuk membersihkan kamar tidur, dan ruang kelas, mengadakan healthy month setiap 2 bulan sekali, bekerjasama dengan Qism Maktabah dalam pengadaan majalah dinding kesehatan, bekerjasama dengan Qism Tarbiyah Wa Ta'lim untuk pemeriksaan santriwati yang mengalami istihadhoh.

c. Program Kerja Mingguan : mengadakan penjemuran kasur yang diadakan setiap 2 minggu sekali, mengadakan syuro' pekanan dihari Sabtu, memberian multivitamin kepada santriwati setiap 1-2 minggu sekali, yang dilaksanakan pada hari jum'at, pengecekan kuku pada hari jum'at pagi.

d. Program Kerja Harian : Pemberian surat izin, mengontrol piket ruang kesehatan, menindak santri wati yang mencoret coret 


\section{Mustika Dewi,Mega Ulfah, Fatmawati, Ningrum Paramita Sari, Nur Aini Retno Hastuti,Rahmadian Hanifa R, Purwarani Febria Damayanti, R.A Rahmawati Nurul F Pembentukan Dan Pembinaan Kelas Remaja Sehat Di Pondok Pesantren}

anggota badan, mendata setiap peminjaman dan pemasukan obat-obat P3K, piket pengecekan santriwati yang sakit.

Santri merupakan kelompok remaja perempuan yang sangat potensial dibina sebagai kader kesehatan reproduksi di pondok pesantren (Maolinda, 2012). Peningkatan pengetahuan pada remaja diharapkan dapat memberikan perubahan sikap dan perilaku mereka terhadap masalah kesehatan reproduksi remaja.Hal ini sesuai dengan penelitian yang dilakukan oleh (Made et al., 2014) yang menyatakan bahwa remaja yang memiliki pengetahuan yang baik akan diikuti dengan sikap yang baik, remaja yang memiliki pengetahuan yang baik akan diikuti dengan aktivitas yang positif dan remaja yang memiliki sikap yang baik akan diikuti juga dengan aktivitas yang positif.

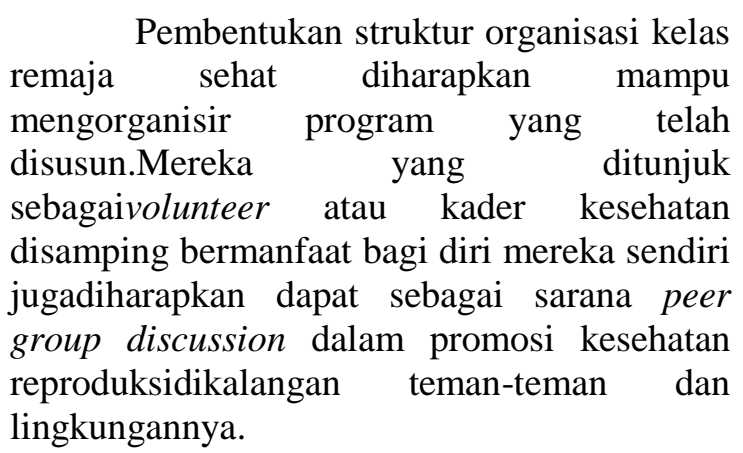

Pelaksanaan pembinaan kelas remaja sehatdiikuti cukup antusias oleh santri untuk mendapatkan pengetahuan tentang kesehatan reproduksi disebabkan real dengan kondisi mereka saat ini, seperti telah disusunnya program kerja kelas remja sehat.Keberlanjutan kelas remaja sehat, dapat di kembangkan dan disesuaikan dengan kebutuhan santri pada kegiatan pengabdian masyarakat berikutnya.Pembahasan tentang menstruasi menjadi hal yang menarik bagi santri, sehingga pada kesempatan berikutnya direncanakan membahas secara tentang siklus menstruasi dan hal-hal yang mempengaruhinya, dengan tema "pengaruh asupan nutrisi terhadap status gizi dan menstruasi remaja di pondok pesantren". Santri telahdibagikannya booklet dengan judul "My Period Diary" dan menjelaskan manfaat serta cara mengisinya sehingga dapat dibahas pada kelas remaja sehat berikutnya (Irianto, 2015).

\section{SIMPULAN}

Pembinaan secara terus-menerus agar terlaksananya program kerja kelas remaja sehat dilakukan guru atau ustadzah pembina pondok pesantren.Pondok pesantren juga dapat dijadikan sekolah binaan yang sustainablepada kegiatan pengabdian masyarakat berikutnya oleh Fakultas Kedokteran Universitas Brawijaya Program Studi S1 Kebidanan.

\section{DAFTAR PUSTAKA}

Andrew, G. (2010). Buku Ajar Kesehatan Reproduksi. (J. Studd, Ed.) (2nd ed.). London, UK: EGC.

Birkeland, M. S., Breivik, K., \& Wold, B. (2014). Peer Acceptance Protects Global Self-esteem from Negative Effects of Low Closeness to Parents During Adolescence and Early Adulthood. Journal of Youth and Adolescence, 43(1), 70-80.

Ellis, W. E., Chung-Hall, J., \& Dumas, T. M. (2013). The Role of Peer Group Aggression in Predicting Adolescent Dating Violence and Relationship Quality. Journal of Youth and Adolescence, 42(4), 487-499.

Ellis, W. E., \& Wolfe, D. A. (2009). Understanding the Association between maltreatment history and adolescent risk behavior by Examining popularity motivations and peer group control. Journal of Youth and Adolescence, 38(9), 1253-1263. 
Mustika Dewi,Mega Ulfah, Fatmawati, Ningrum Paramita Sari, Nur Aini Retno Hastuti,Rahmadian Hanifa R, Purwarani Febria Damayanti, R.A Rahmawati Nurul F

Pembentukan Dan Pembinaan Kelas Remaja Sehat Di Pondok Pesantren

Gorrese, A., \& Ruggieri, R. (2012). Peer attachment: A meta-analytic review of gender and age differences and associations with parent attachment. Journal of Youth and Adolescence, 41(5), $650-672$.

Irianto, K. (2015). Kesehatan Reproduksi, 1812.

Kemenkes RI. (2014). Situasi Kesehatan Reproduksi Remaja. Pusat Data dan Informasi Kesehatan.

Made, I., Wijaya, K., Nyoman, N., Agustini, M., Doddy, G., Ms, T., \& Artikel, I. (2014). Pengetahuan, Sikap Dan Aktivitas Remaja Sma Dalam Kesehatan Reproduksi Di Kecamatan Buleleng. Kemas, 10(1), 33-42.

Maolinda, N. et al. (2012). Kesehatan Masyara. Sampling Techniques, 3. https://doi.org/doi:10.1201/97814200424 98.ch16

Marion, D., Laursen, B., Zettergren, P., \& Bergman, L. R. (2013). Predicting Life Satisfaction During Middle Adulthood from Peer Relationships During MidAdolescence. Journal of Youth and Adolescence, 42(8), 1299-1307. https://doi.org/10.1007/s10964-0139969-6 